\title{
The Third Dimention of Education: It's Relevance in the New Millennium
}

\author{
N. K. Mahakud and B.Panda* \\ P.G. Department of Sociology, Sambalpur University, JV, Burla, Orissa, India \\ *P.G. Department of Home-Science, Sambalpur University, JV, Burla, Orissa, India
}

\begin{abstract}
KEYWORDS Extension education; community service; campus community linkage; community assets; national integration

ABSTRACT NSS as one of the component of the third dimension of education has been carried on in a voluntary spirit in a large number of educational institutions of the country since 1969. It needs to be evaluated to know its relevance. A very few such evaluations has been made which do not cover the whole aspect of it. The present paper attempts to fill up this gap by making use of the management concept of SWOT ( strength, weakness, opportunity and threat). The analysis is based on the method of content analysis. The proceeding of various meetings, deliberations of dignitaries in the programmes of celebrations, etc have been scrutinized as the source information. It is observed that the constraints (weakness and threat) are mostly organizational in nature which can be very easily overcome and NSS can be made very effective particularly in shaping the youth energy and which can be made use of in the process of social welfare and national development.
\end{abstract}

\section{INTRODUCTION}

Education, being an important instrument of social change and national development, a lot has been altered and added to make it socially more relevant during the post independent period. The most significant is the addition of a new dimension to teaching and research, after being accepted by the Vice-Chancellors in their All India Conference in 1967. This is popularly known as the Third Dimension of Education or the Extension of Education, which constitutes NCC, NSS, Adult Education, Population Education, and Woman Development Programme. This composite extension service became imperative for the Universities. This new dimension is aimed to fulfill the much-needed social requirements by inculcating the social relevance in the minds of the students of the higher education. The students and the teachers should be sensitized with poverty, unemployment and illiteracy; the major constraints to social and national progress (Prakash, 1955). Further, expose to field reality of the students and teachers will enhance the scope of linking the class-room knowledge with the community and thereby, education can be made more realistic. "They should be able to render social service, help in building community assets and contribute to social and economic development plans where they can use the knowledge acquired in class" (Saha, 1977).

\section{GENESIS}

Long before the addition of the third dimension of education, as early as 1948, Dr. S. Radhakrishnan, the Chairman of the education Committee, suggested for a linkage between the campus (teacher and student) and community, which was endorsed by Central Board of Education (1950). The University Education Commission declares that "The life of school should follow the course of life of a good village except that about half of the working time would be given to study and half to practical work" (1948-49: p. 564). The Ministry of Education introduced a scheme in 1956 known as Village Apprenticeship Training Scheme for the University students to undergo training and get expose in the developmental activities being carried out under Community Project (Madan, 1967). Realising the success of the scheme Pandit Jawaharlal Nehru in 1958 endorsed the same to the Chief Ministers, Education Commission (1959), Education Ministers of the states (1961) and the National Service Committee (1964) have also recommended in support of involving the collegiate in social service for 9 to 12 months for persons leaving high or higher secondary schools. A study was sponsored by the Ministry of Education on National Services in Western countries, which was published entitled "National Service for Youth" by Prof. K.C. Saiyidian. He 
recommended that students may be introduced with National/Social Service at college and university level on voluntary basis. On the similar line Dr. D. S. Kothary, Chairman of the Education Commission (1964-66) stressed that students at all levels of education should be associated with some form of social service. The Conference of Education Ministers and the Vice- Chancellors held in the month of April and September respectively in 1967 recommended that the university students should join NCC, NSS or NSO. Finally, the conference of the students of Universities and Institutions of higher learning convened by the Ministry of Education and University Grant Commission in May 1969 declared that NSS could be a powerful instrument for national integration. Immediately in the same year the Planning Commission provided an outlay of Five crore and was launched by the then Education Minister Dr.V.K.R.V.Rao on $24^{\text {th }}$ September 1969 on the eve of Gandhi Centenary Year (Mahakud, 2001: 10).

\section{NSS: A BIRD'S EYE VIEW}

NSS as the third dimension of Education, a Classroom-Lab-Community Programme aims to create skill and knowledge and awareness of our glorious national heritage and the achievements of human civilization, possessing a basic scientific outlook and commitment to the ideals of "Service to Man is Service to God," patriotism, democracy secularisms, fraternity, equality, social justice as enunciated in the Preamble of our Constitution. The main objective of NSS is to prepare its volunteers in the democratic, selfdisciplined and self-reliant way of life. The motto or the catch word of NSS is 'NOT ME BUT YOU'. It is, therefore, of vital importance that the NSS units are organised and run on democratic lines. The student leaders, NSS Volunteers and other members of the staff, and eminent personalities from the community are associated with it. They are encouraged to participate in planning, execution and evaluation of NSS programme.

Therefore, it aims at:

i. Encouraging students and non-students to work together along with the people in rural areas.

ii. Developing qualities of leadership by discovering the latent potential among the campers, both students as well as local youth (Rural and Urban), with a view to involve them more intimately in the development programme and also to ensure proper maintenance of the assets created during the camps.

iii. Providing opportunities to the students to play their role in planning and executing development projects would not only help in creating durable community assets in rural areas and urban slums but also results in the improvement of quality of life of the economically and socially weaker sections of the community.

iv. Making education more relevant to the present situation to meet the felt needs of the community and supplement the education of the university/college students by bringing them face to face with the rural situation.

v. Removing barrier between the educated and uneducated youth and promote solidarity.

vi. Promoting a desire among the youth between the age of 16 and 21 to be socially useful by participating in the social activities.

The activities under NSS are broadly categorized into two, viz. Regular Activity (RA) and Special Camping Programme (SCP). While regular activity constitutes a minimum period of 120 hours per year of day-to-day activities, Special camping refers to Ten Day's Camping activities in the adopted village or slum. A volunteer has to participate in regular activities for a minimum of 120 hours in a year and has to attend one special camp of ten day's duration. Except 20 hrs. orientation on NSS and 30 hrs. Campus activities, the rest of the $70 \mathrm{hrs}$. of regular activity and the special camps are organized in the adopted village or slum. The activities during this period are undertaken with participation of the people of the concerned village or slum. "Dignity of labour" is the spirit in which the student volunteers render both menial and manual services to the community. These activities aim at providing opportunity to the students to stir up their latent potential and to make use of them in planning and execution of developmental projects with full participation along with the nonstudent rural youth and adult through cooperative living and cooperative action (NSS Manual, 1997: 10)

NSS thus, ensures that the academic excellence among teachers and students contributes to the society. Under the constant scrutiny of his students a teacher inculcates the knowledge and spirit of a responsible citizen both in percepts and practice. NSS, a programme of Teacher and 
Student aims to mould the tender heart of the youth to recognise himself with his own society and nation through community participation with a spirit of voluntarism. Thus, NSS is for the student youth and the people, by the teachers and students of higher educational institutions.

NSS from 37 Universities with 40,000 volunteers in the beginning in 1969 to 158 Universities, and +2 institution with 16.7 lakhs volunteers at present indicates its potentialities to grow with recognition. Even with the notion of voluntarism it could have gathered such a huge mass of educated youth with full command over them. There is no other organization having such a nation-wide large-scale network in the world.

Further, NSS being the programme by the teachers and students, who are the cream of the society, and for the student youth and community in particular and for the society and nation in general is a very relevant programme for development. As a programme of class roomlab-community, it needs to be the most effective and beneficial to the society. The rate of institutional increase in average and the growth rate of volunteers connote the growth and development of NSS but its wide range of recognition in the country.

But, in spite of its quantitative growth, its achievement in qualitative term is not identical. The few evaluation reports (made by Thakur and Chandra, IIPA, 1996-97; Mohammad and Soman, 2000 and SWOT analysis at Wardha, 2000) have pointed out a bundle of weaknesses and simultaneously suggested some remedial measures for the improvement of the scheme. While the first study has focused more on organizational problems, the second has confined its scope among the volunteers and non-volunteers. The last analysis made at Wardha was broad based in terms of area and participation of the cross section of NSS functionaries.

Making an account of the above facts, the present piece of paper is an attempt to analyse NSS on SWOT ( strength, weakness, opportunity and threat ) model based on the excerpts of the proceedings of the four regional meetings of the Principals of colleges, Programme Officers, along with other functionaries of Regional, State and University level organized by one of the authors ( N.K.Mahakud ) as Programme Coordinator of Sambalpur University from May 1999 to May 2002. The deliberations and discussions on the observation of various ceremonies and functions related to NSS are analysed, where dignitaries, academicians, former and officiating NSS functionaries are the important participants. The content of those resolutions are classified in to SWOT. Thus this evaluative paper is based on a method called content analysis.

The basic questions, which are addressed in this explanation are:

a. Whether the opportunities provided in the scheme for the student, teacher and above all the people are being availed by them as intended in terms of aims and objectives of the scheme?

b. Whether these opportunities put any impact on the students and teachers and they make use of them in their future life?

c. To what extent the answers to the above questions are positive upon which the success of the scheme depends on?

Answers of the above questions automatically highlight the weaknesses and threats, which are also to be recorded, particularly to propose a set of remedial measures especially, to make the scheme more relevant and viable in the New Millennium. Or in other words, if the strength of the scheme and the opportunity provided in it surpass the weakness and overcome the threats, than the scheme is assumed to be successful and relevant in the contemporary society.

\section{ANALYSIS}

The relevance (as Strength) of the scheme as inferred from the documents mentioned above are mentioned below.

1. NSS based on the notions of voluntarism commands a huge mass of youth force (No other organisation has) of the country. It as a movement based on strong Indian values like non-violance, tolerance and promotes national character. It brings youth closer to Gandhian philosophy and ideology of "Dignity of Labour", "Service to Man is Service to God" and the democratic spirit, "Not Me But You".

2. Academic and intellectual base make its activities free from any political or bureaucratic interference.

3. NSS is a classroom-lab-community-friendly Programme and it provides opportunity to work in human-laboratory (people and community). Hence, it helps to insulate scientific value into traditional culture and 
can bring / accelerate change in the society.

4. NSS is an effective instrument for removing social stigma, blind beiliefs, prejudices of caste, creed and religion, and for development of solidarity among people of different ethnic group.

5. NSS activities centering on Literacy, Plantation, Watershed Management, fight against Disaster, National Integration, Youth Exchange and Interaction, Adventures etc. can bring success in terms of development of personality of the students and can benefit the people in resolving their problems and creating durable assets for the community.

6. The composition of Advisory Committee starting from village level to State level and the process of selection of projects both Micro and Macro becomes most suitable and viable for the community and the nation as a whole.

7. As NSS establishes Nation-wide Net Work, it covers the nook and corner of the whole nation through the affiliated +2 and +3 colleges.

8. It promotes the spirit of Nationalism and National Integration among the youth and the others.

9. It is a low cost movement for reaching from Campus to Community. Thus NSS is a "maximum output with minimum input programme" implemented by the educational institution under the supervision and monitoring of college teachers, the highly dignified intellectuals of the society.

10. It creates discipline among student volunteers preparing for a responsible citizen for the future through classroom and community participations. Thus, it has its potentiality to canalize Youth Energy, through wellorganised Youth activities. It develops skill on the reciprocal basis of harmony between society and youth through cooperative work and living.

11. NSS exposes the students with the empirical world of life and with practical experience. This may create interest in them for social work and engage him in leisure time, keep him for a while away from the bookish boredom and indirectly reduce student unrest in the educational institutions as a whole.

In spite of the above strength, NSS suffers from some weaknesses, the mention of which is imperative to think for its greater success. They are:
1. While the scheme is sponsored by the Ministry of Youth Affairs and Sports, it is implemented through the Universities and colleges which are under the direct control of the Department of Education. Hence, communication gap is observed at organizational level and the academic intellectuals show an indifferent attitude towards the scheme.

2. Lack of training and orientation of NSS functionaries, particularly the Principals, who are the Chief functionaries at unit level under whose guidance and supervision all the activities are carried out. Similarly large number of Programmed Officers do not get training immediately after their appointment. As a result NSS activities are neither properly planned nor effectively implemented.

3. Marginal recognition of NSS functionaries and underestimation of student participation in community by Welfare Agencies and hence, inadequate response from local administration

4. Lack of timely supervision, monitoring and evaluation by the higher authorities. It is reported that regular activities are never supervised by any of the functionaries of NSS. But the functionaries of University, State and Regional Centre supervise only the Special Camping Programmes.

5. Lack of lucrative incentive both for the teachers and the students. The provision of awards does not give teachers any academic credit neither in open selection nor in carrier advancement. The volunteers also do not get any advantage in their future life.

Further, NSS provides the following opportunities to all its members by:

1. NSS provides scope to develop personality of educated youth mass and to identify themselves with local community and nation as a whole through community service

2. It provides opportunity to work in humanlaboratory (people and community) and thereby develops inter-personal and other skill.

3. NSS generates human and material resources in collaboration with other systems (for e.g.Industrial houses, Govt. organisations and Non-Govt. organisations) indirectly. It associates students with Government and nongovernmental organizations working in identical field, 
4. It harnesesss expertise from Education, Research, Professional Institutes, Govt. and Non-Govt. Organisations and from the community. Generating expertise from with in the group.

5. It generates sensitivity on relevant/current issues and sensitise Campus and Community to ensure meaningful participation.

6. It is an occasion for conceptualising new, modifying the existing concepts and approaches, methods tools and techniques to understand the social situation.

7. NSS volunteers involve themselves in Event Management and crisis management.

8. Students get scope for the contribution in areas of National concern and National exigencies.

9. NSS makes its volunteers best Social Catalyst for change and development in society.

The measure threats for NSS are:

1. Ad hocism, particularly the tenure (3-4 years) appointment of State and University functionaries (SLO and Programme Coordinator) and the Programme Officers at College level, often creates vaccum and hampers in the continuity of programme.

2. Lack of the spirit of voluntarism and the interest for social service among the regular employees of the Ministry. On the other hand undue bureauctatic influence and interference losses the spirit of voluntarism.

3. Increase in academic burdens both on the teacher and students discourage involvement in NSS.

4. Improper utilization of fund is another threat for proper implementation of NSS activities.

\section{PROLOGUE}

Prakash (2000) has observed that with the spread of higher education, colleges and Universities, the youth are visible with their manifested actions, idioms, outlooks and challenging lifestyle. They are under the negative influence of Western and modern culture and caught in the vortex of changing values and attitude of tradition and transitional societies. These two social processes have induced new life goals and values for youth popularly known as six CSociety, which stands for Car, Credit Card, Condominium, Corporate Job, Charisma and Cash. These are the status symbols of the youth of the day.
In the context of the above fact the role of the third dimension of education in general and NSS in particular is very much important to show a proper direction to the youth community and make use of their powerful energy in nation building. At the advent a new millennium it is really high time to make an evaluation and to search for its social relevance. NSS, being an innovative programme, as a scope of very wide range by developing the personality of the youth, the future of the society to serve the community and to meet the needs of the people, to face the challenges of life, to overcome the hurdles of progress. Thus, it commands a great social relevance compared to any other program. However, in order to achieve this objective, the weaknesses and threat for NSS are to be overcome and convert them into strength \& opportunity. They being the organizational problems, they can easily be resolved at policy and planning level and consequentially, NSS as one of the components of the third dimension of education become very much functional and relevant in the 21 st century, particularly in canalizing the youth energy into the developmental process of the country.

\section{REFERENCES}

Madan, G.R. 1967. Indian Social Problem, (Social Work) V.2. Bombay: Allied Publishers.

Mahakud, N.K. 2001. "Assement of NSS activities in search of Social relevance Yuva Seva." NSS Bulletin, Vol. 1, Issue No. 1, NSS Cell. Jyoti Vihar Burla, Orissa: Sambalpur University.

Ministry of Education. 1986. National Policy on Education. New Delhi.

Prakash, Bhagbhan. 1995. "Achieving Special Reliance Through NSS" in Samaj Seva, Silver Jubilee Issue, TORC, Kolcota, Pp.14-25.

Prakash, Bhagaban. 2000. 21 ${ }^{\text {st }}$ Century: Development Challenges. Chandigarh.Commonwealth Secretariat, Commonwealth Youth Programme.

Saha, A.K. 1977. "Textension Education - The Third Dimension: Needs and Aspiration of Indian Youth." Paper presented in the National level symposium on Youth in Academic Institution, January1977, at Mysore University.

Saha, A.K. 1977 "Integrated Youth Development - NSS Approach." Unpublished paper.

Saha, A.K. 1977. "Social Service with a smile." The Telegraph, 10.4

Saiyidian,K.G. 1961. National Service Sheme-A Report. New Delhi: Ministry of Education, Govt. of India.

Thakur, R.N. and S. K. Chandra. 1996-97. Evaluation of NSS Programme and Organisational Structure in All India Basis. New Delhi: Indian Institute of Public Administration (IIPA), Unpublished Report. 